\title{
ANALYSIS OF STUDENTS SCIENTIFIC CONSITENCY AND REPRESENTATION CONSISTENCY ON RECTILINEAR MOTION KINEMATICS MATERIAL GRADE X IN SMAN 8 PEKANBARU
}

\author{
Inike Paramita ${ }^{* 1)}$, Yennita ${ }^{2)}$, Fakhruddin $Z^{3)}$ \\ ${ }^{1,2,3)}$ Physics Education, University of Riau \\ e-mail: inikeparamita@gmail.com \\ yennitacaca@yahoo.com \\ faruqfisika@yahoo.com
}

\begin{abstract}
This study wasaimed to describe the level of student scientific consistency and representation consistency of class X SMA Negeri 8 Pekanbaru on rectilinear motion kinematisc material. The type of research was survey research. The subject of this research were 70 students. The data collection of this research used test, instrument of research used scientific consistency and representation consistency test the form of objektive matter which consist of 21 question wiht seven themes, each theme consist off three question with the same concept but presented in different representatiton. Descriptive analysis was used to analyze the data which showed the level of scientific consistency and representation consistency. The results showed that thepercentage of student at each scientific consistency level was $14.29 \%$ for consistent scientific, $20.00 \%$ for moderately consistent scientific and $65.71 \%$ for inconsistent scientific, while overall the students were at inconsistent levels for scientific consistency or that can be said they have no consistencyscientific. For representation consistency, the percentage ofstudents at each successive level was $17.14 \%$ for consistent representation, $28.57 \%$ for moderately consistent representation and $54.29 \%$ for inconsistent representation, while overall students were at moderately consistent representation level, mean that studentshave consistencyrepresentation.
\end{abstract}

Keywords: rectilinear motion kinematics, representation consistency, scientific consistency.

\section{ANALISIS KONSISTENSI ILMIAH DAN KONSISTENSI REPRESENTASI SISWA SMA PADA MATERI KINEMATIKA GERAK LURUS KELAS X DI SMAN 8 PEKANBARU}

\author{
Inike Paramita ${ }^{* 1)}$, Yennita ${ }^{2)}$, Fakhruddin $Z^{3)}$ \\ ${ }^{1,2,3)}$ Pendidikan Fisika, Universitas Riau
}

\begin{abstract}
Abstrak
Penelitian ini bertujuan untuk mendeskripsikan tingkat konsistensi ilmiah dan konsistensi representasi siswa kelas X SMA Negeri 8 Pekanbaru pada materi kinematika gerak lurus. Jenis penelitian yang digunakan merupakan penelitian survei. Adapun subjek penelitian ini adalah 70 orang siswa. Teknik pengumpulan data penelitian ini melalui tes, dengan menggunakan interumen tes konsistensi ilmiah dan konsistensi representasi berupa soal objektif berjumlah 21 soal dengan tujuh tema, dimana tiap tema terdiri dari tiga soal dengan konsep yang sama tetapi disajikan dalam bentuk representasi berbeda. Analisis data hasil penelitian ini menggunakan analisis deskriptif, yang memberikan gambaran tentang tingkat konsistensi ilmiah dan konsistensi representasi. Hasil penelitian menunjukkan bahwa persentase siswa pada tiap level konsistensi
\end{abstract}


ilmiah berturut-turut sebanyak 14.29\% konsisten ilmiah, 20\% cukup konsisten ilmiah dan $65.71 \%$ tidak konsisten ilmiah, sedangkan secara keseluruhan siswa berada pada tingkat tidak konsisten untuk konsitensi ilmiah atau siswa dikatakan belum memiliki konsistensi ilmiah. Untuk konsistensi representasi, persentase siswa pada tiap level berturut-turut sebanyak $17.14 \%$ konsisten representasi, $28.57 \%$ cukup konsisten representasi dan 54.29\% tidak konsisten representasi, sedangkan secara keseluruhan siswa berada pada tingkat cukup konsisten atau siswa dikatakan sudah memliki konsistensi representasi.

Kata kunci: kinematika gerak lurus, konsistensi ilmiah, konsistensi representasi.

\section{Pendahuluan}

Pelajaran fisika merupakan pelajaran yang penting bagi siswa karena pelajaran fisika memiliki potensi yang besar untuk dijadikan wahana mengembangkan kemampuan. Salah satu kemampuan yang perlu dikembangkan adalah kemampuan representasi (Fathoroni, 2016). Menurut Goldin (2002) representasi adalah suatu konfigurasi (bentuk atau susunan) yang dapat menggambarkan, mewakili atau melambangkan sesuatu dalam satu cara.

Kemampuan representasi dalam fisika meliputi kemampuan siswa dalam mempresentasi ulang informasi yang diperoleh (Etkina et al., 2006). Keterampilan representasi adalah kemampuan yang harus dimiliki untuk menginterpretasi dan menerapkan berbagai konsep untuk memecahkan masalah-masalah secara tepat. Sedangkan multi reprsentasi (representasi majemuk) adalah representasi konsep yang dilakukan lebih dari satu cara. Dengan menggunakan representasi majemuk dalam pembelajaran fisika akan memberikan banyak manfaat, diantaranya mengasah kemampuan intelegensi (kecerdasan) siswa secara beragam atau lebih dikenal dengan istilah intelegensi majemuk (multi intelegensi) (Kohl \& Noah, 2008).

Umumnya guru fisika saat ini bukan mengajar fisika tetapi mengajar matematika dengan contoh-contoh soal fisika. Hal tersebut dapat dilihat dari proses pembelajaran fisika yang cenderung menggunakan representasi matematik dan terlalu banyak menghabiskan waktu dalam penurunan rumus matematika (Aminudin et al., 2013). Untuk mempelajari fisika secara efektif siswa harus memahami penggunaan representasi dalam menjelaskan suatu konsep fisika dan mampu menerjemah kan representasi-representasi suatu konsep dari satu bentuk ke bentuk lainnya (Fatmawati, et al., 2015). Kemampuan multi representasi yang terdiri dari representasi verbal, matematik, grafik, dan gambar yang mewakili pengetahuan dan keterampilan. Kemampuan representasi verbal dan matematik mewakili pengetahuan, sedangkan representasi grafik dan gambar mewakili keterampilan (Dya, et al., 2015).

Fungsi utama multi representasi diantaranya melengkapi informasi, membatasi kesalahan interpretasi representasi lain, dan membangun pemahaman yang lebih mendalam (Binar, 2015). Memiliki keterampilan dalam menggunakan berbagai macam representasi dan mengkoordinasikan multi representasi sangat menguntungkan dalam mempelajari fisika, selain sebagai alat untuk memahami konsep, keterampilan itupun dapat memudah kan dalam memecahkan masalah (Abdurrahman, et al., 2008).

Perbedaan konteks dan sajian soal dapat menimbulkan perpedaan respon dari siswa, bahkan sekalipun konsep yang mendasarinya identik (Sriyansyah, 2015). Menurut Ainsworth (2006) konsistensi respon siswa dalam memahami konsep fisika menuntut pemahaman yang lebih dari siswa untuk melihat kesetaraan dari permasalahan fisika yang dituangkan dengan berbagai cara. Dampak tidak langsung dari kekonsistenan tersebut adalah terhadap konsistensi representasi dan konsistensi ilmiah. Konsistensi representasi merupakan kemampuan menggunakan representasi yang berbeda secara konsisten (baik benar atau salah) pada soal-soal yang memiliki konteks dan konten yang sama, sedangkan konsistensi ilmiah merupakan kasus khusus dari konsistensi representasi yang hanya dimiliki jika dari segi representasi dan dari segi ilmiah jawaban siswa benar (Nieminen, et al., 2010).

Konsistensi ilmiah dan konsistensi representasi sangat penting dimiliki siswa, sebab kemampuan ini berkaitan dengan 
pemahaman konsep. Asumsi ini diperkuat dengan hasil penelitian Nieminen et al. (2012) yang menemukan bahwa terdapat hubungan positif yang kuat antara tingkat konsistensi representasi pra-instruksi dengan peningkatan pembelajaran pada konsep gaya.

Selain berkaitan dengan pemahaman konsep, konsistensi ilmiah dan konsistensi representasi juga berkaitan dengan kemampuan siswa dalam menggunakan multi representasi. Penelitian Suhandi \& Wibowo (2012) juga menyatakan bahwa multi representasi memerankan peranan yang sangat penting dan kerap kali dibutuhkan dalam memahami konsep, memecahkan masalah, menanamkan pemahaman konsep, serta membangun pemahaman yang lebih mendalam.

Berdasarkan penjelasan sebelumnya, terlihat bahwa konsistensi ilmiah dan konsistensi representasi penting bagi siswa, akan tetapi gambaran mengenai tingkat konsistensi ilmiah dan konsistensi representasi siswa belum diketahui, maka penelitian dilakukan untuk mengetahui tingkat konsistensi ilmiah dan konsisitensi representasi siswa dengan judul penelitian "Analisis Konsistensi Ilmiah dan Konsistensi Representasi Siswa SMA pada Materi Kinematika Gerak Lurus Kelas X di SMAN 8 Pekanbaru".

\section{Bahan dan Metode}

Penelitian dilakukan di SMA Negeri 8 Pekanbaru pada bulan Maret-Mei 2018. Subjek penelitian ini adalah 70 siswa kelas X SMA Negeri 8 Pekanbaru. Instrumen penelitian yang digunakan adalah tes konsistensi ilmiah dan konsistensi representasi. Jenis penelitian ini merupakan penelitian survei dengan prosedur penelitian yang dikembangkan berdasarkan langkah-langkah penting dalam penelitian survei menurut Gambar 1.

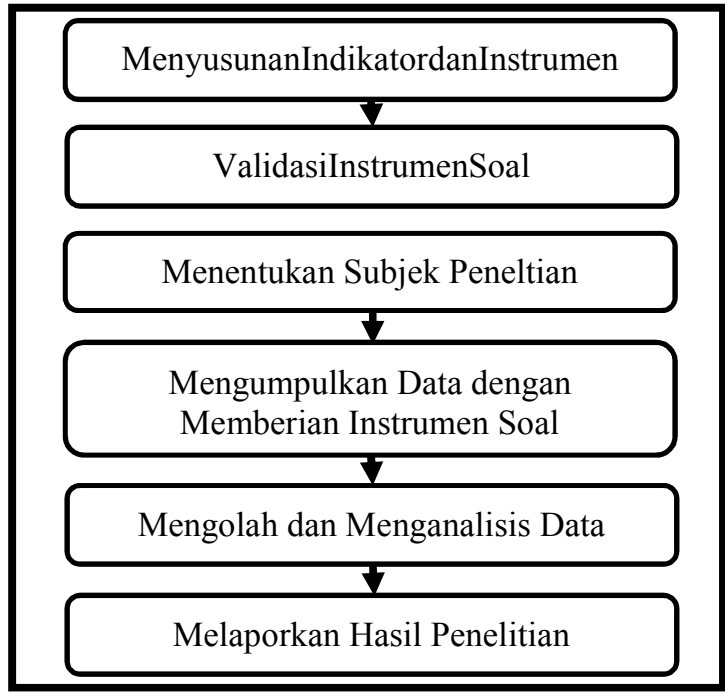

Gambar 1. Prosedur penelitian (Sukardi, 2015).

Tabel 1 Tingkat konsistensi ilmiah berdasarkan perhitungan skor rata- rata

\begin{tabular}{|c|c|}
\hline Skor Rata-rata & Kategori \\
\hline $1.70 \leq \mathrm{SR} \leq 2.00$ & Konsisten Ilmiah \\
\hline $1.20 \leq \mathrm{SR} \leq 1.69$ & $\begin{array}{l}\text { Cukup Konsisten } \\
\text { Ilmiah }\end{array}$ \\
\hline $0.00 \leq \mathrm{SR} \leq 1.19$ & $\begin{array}{l}\text { Tidak Konsisten } \\
\text { Ilmiah }\end{array}$ \\
\hline
\end{tabular}

Ket. SR $=$ Skor Rata-rata.

Teknik analisis data yang digunakan merupakan teknik deskriptif, Teknik ini melalui dua tahapan, yaitu penilaian/scoring dan kemudian diinterprestasikan dalam tiga kategori konsistensi. Aturan pemberian skor didasarkan menurut aturan dari Nieminem, et al. (2010) yaitu: a) Skor 2, jika memilih tiga pilihan jawaban yang berhubungan (dari segi representasi) dari tiga butir soal dalam satu tema; b) Skor 1, jika memilih dua pilihan jawaban yang berhubungan (dari segi representasi) dari tiga butir soal dalam satu tema; c) Skor 0, jika tidak ada satu pun pilihan jawaban yang saling berhubungan (dari segi representasi) dari tiga butir soal dalam satu tema. Untuk konsistensi ilmiah, penskoran berlaku hanya jika jawaban siswa benar, sedangkan untuk konsistensi representasi penskoran berlaku selama siswa memilih pilihan jawaban yang berhubungan dari segi representasi, baik jawabannya benar maupun 
salah. Dalam penelitian ini, peneliti mengguna kan kategori tingkat konsistensi ilmiah berdasarkan Tabel 1 dan konsistensi representasi siswa berdasarkan Tabel 2 .

Tabel 2 Tingkat konsistensi representasi berdasarkan perhitungan skor rata- rata

\begin{tabular}{|c|c|}
\hline Skor Rata-rata & Kategori \\
\hline \multirow{2}{*}{$1.70 \leq \mathrm{SR} \leq 2.00$} & Konsisten \\
\hline & Representasi \\
\hline \multirow{2}{*}{$1.20 \leq \mathrm{SR} \leq 1.69$} & Cukup Konsisten \\
\hline & Representasi \\
\hline \multirow{2}{*}{$0.00 \leq \mathrm{SR} \leq 1.19$} & Tidak Konsisten \\
\hline & Representasi \\
\hline
\end{tabular}

Nieminen, et al. (2010)

Skor rata-rata siswa didapat dari penjumlahn skor dari tiap-tiap tema kemudian dibagi banyaknya tema. Siswa dapat dinyatakan sudah memiliki konsistensi ilmiah jika mampu mendapat skor rata-rata konsistensi sebesar 1.20 sampai 2.00 (cukup konsisten dan konsisten) dan siswa dikatakan belum memiliki konsistensi apabila mendapat skor rata-rata konsisistensi kurang dari 1,20 (tidak konsisten), hal ini berlaku unruk kedua konsistensi yaitu konsistensi ilmiah dan konsistensi representasi.

\section{Hasil dan Pembahasan}

Soal tes tingkat konsistensi ilmiah dan konsistensi representasi diujikan dengan 21 butir soal yang dikembangkan berdasarkan 7 tema yang telah ditentukan yaitu posisi dan perpindahan, kecepatan dan kelajuan, percepa tan, gerak lurus beraturan, gerak lurus berubah beraturan, gerak vertikal ke atas dan gerak vertikal ke bawah dan terkahir gerak jatuh bebas.

Persentase siswa terhadap tingkat konsistensi ilmiah sebagaimana terlihat pada Gambar 2 dan persentase siswa terhadap tingkat konsistensi representasi pada Gambar 3.

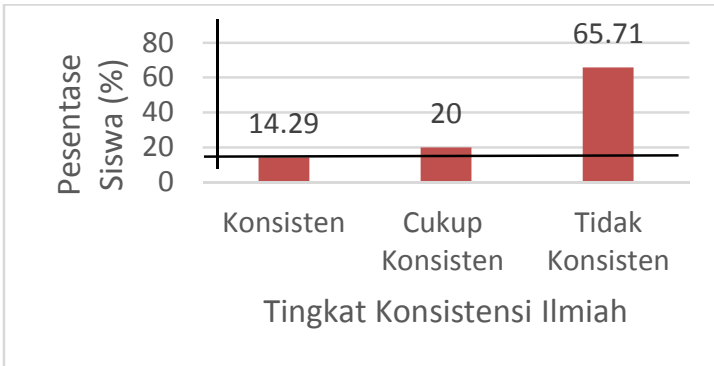

Gambar 2. Persentase siswa terhadap tingkat konsistensi ilmiah.

Berdasarkan Gambar 2 terlihat bahwa siswa yang tidak konsisten ilmiah masih lebih banyak dibandingkan siswa yang konsisten ilmiah (konsisten dan cukup konsisten), untuk hasil perhitungan rata-rata skor semua siswa adalah 0.9 dalam kategori tidak konsisten ilmiah.

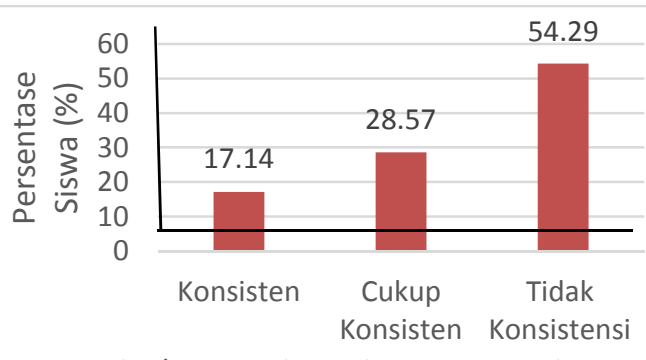

Tingkat Konsistensi Representasi

Gambar 3. Persentase siswa terhadap tingkat konsistensi representasi.

Gambar 3 memperlihatkan bahwa siswa yang tidak konsisten representasi masih lebih banyak dibanding siswa yang konsisten representasi (konsisten dan cukup konsisten), tetapi untuk hasil perhitungan persentase ratarata skor semua siswa adalah 1.21 dengan kategori cukup konsisten representasi.

Konsistensi ilmiah dan konsistensi representasi siswa pada tiap tema dapat dianalisis sebagai berikut.

\section{Tema 1 posisi dan perpindahan}

Representasi yang digunakan pada tema 1 adalah verbal-gambar, verbal-matematis dan gambar-verbal, dimana pada tema ini siswa dituntut agar bisa konsisten dalam pemahaman arah dan pembentukan sudut.Besarnya persentase siswa pada tiap skor konsistensi ilmiah secara lebih lengkap dapat dilihat pada Gambar 4 dan untuk konsistensi representasi dapat dilihat pada Gambar 5. 


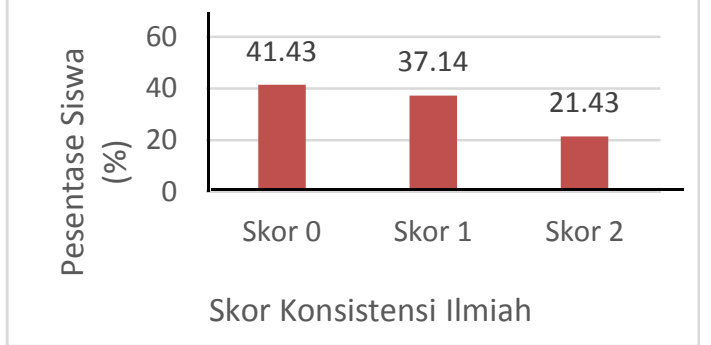

Gambar 4. Persentase siswa terhadap skor konsistensi ilmiah tema 1.

Gambar 4 menunjukkan bahwa masih banyak siswa yang belum bisa konsisten dan belum benar dalam memahami makna arah dan pembentukan sudut yang dimaksud pada ketiga soal yang disajikan.

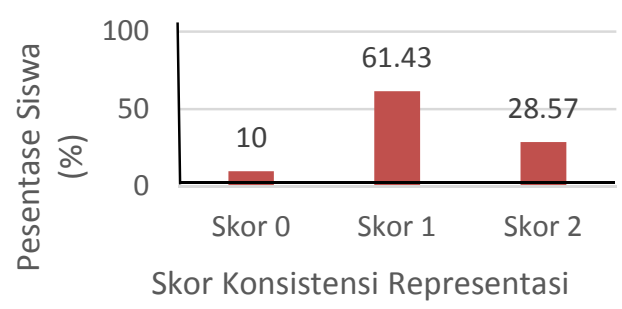

Gambar 5. Persentase siswa terhadap skor konsistensi representasi tema 1.

Pada Gambar 5 dapat dilihat bahwa sebagian besar siswa sudah konsisten dalam segi representasi dalam menentukan arah dan sudut.

Rata-rata skor konsistensi ilmiah yang diperoleh siswa pada tema 1 adalah sebesar 0.80 (tidak konsisten ilmiah) dan konsistensi representasi 1.20 (cukup konsisten representasi). Hal ini mengartikan pada pemahaman arah dan sudut siswa sudah konsisten dalam representasinya tetapi belum konsisten jika dilihat dari segi kebenaran sesuai konsep.

Tema 2 kecepatan dan kelajuan

Representasi yang digunakan pada tema 2 adalah gambar-grafik, tabel-verbal dan verbal-gambar. Pada tema ini siswa dituntut agar dapat konsisten dalam pemahaman pergerakan benda dalam segi kecepatan.

Besarnya persentase siswa terhadap skor konsistensi ilmiah secara lebih lengkap dapat dilihat pada Gambar 6 dan untuk konsistensi representasi dapat dilihat pada Gambar 7.

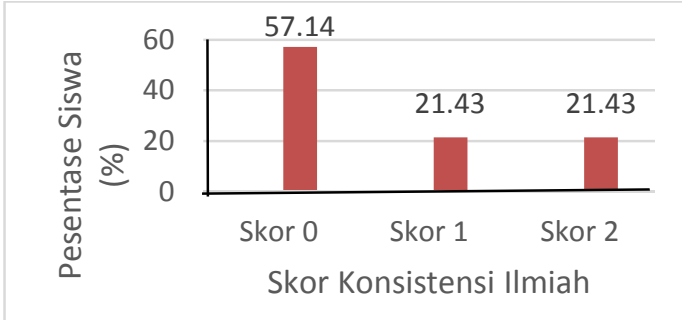

Gambar 6. Persentase siswa terhadap skor konsistensi ilmiah tema 2.

Pada Gambar 6 terlihat bahwa masih banyak siswa yang belum konsisten dan belum benar dalam memahami konsep kecepatan benda.

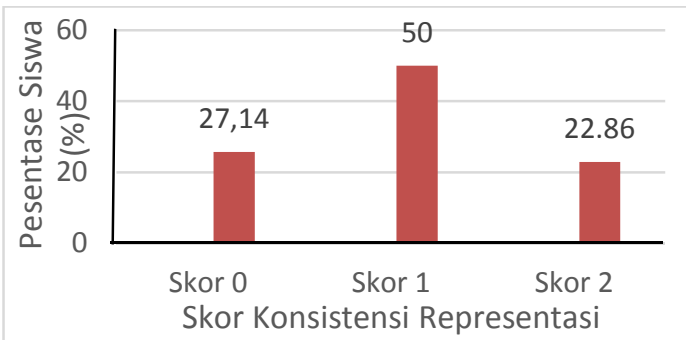

Gambar 7. Persentase siswa terhadap skor konsistensi representasi tema 2.

Berdasarkan Gambar 7 dapat dilihat bahwa sudah lebih sebagian siswa cukup konsisten dalam membedakan kecepatan benda, walaupun yang dapat konsisten seutuhnya pada ketiga soal masih sedikit.

Rata-rata skor konsistensi ilmiah siswa pada tema 2 sebesar 0.64 (tidak konsisten ilmiah) dan rata-rata skor konsistensi representasi siswa pada tema 2 sebesar 0.96 (tidak konsisten representasi). Ini menandakan bahawa pada tema ini siswa belum bisa konisten membedakan bagaimana bentuk diagram/gambar ataupun grafik/tabel benda yang bergerak dengan kecepatan lebih lambat/lebih cepat.

\section{Tema 3 pecepatan}

Representasi yang digunakan pada tema 3 adalah gambar-matematis, verbal-matematis dan grafik-matematis. Pada soal ini siswa dituntut agar dapat konsisten dalam menentukan waktu 2 buah benda memiliki kecepatan yang sama dengan salah satu bendanya memiliki percepatan.

Besarnya persentase siswa pada tiap skor konsistensi ilmiah secara lebih lengkap dapat dilihat pada Gambar 8 dan untuk 
konsistensi representasi dapat dilihat pada Gambar 9.

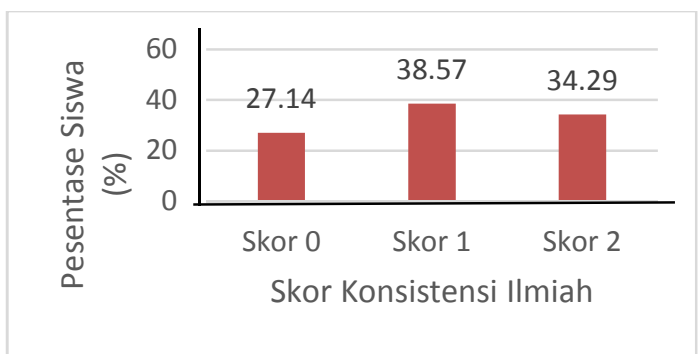

Gambar 8. Persentase siswa terhadap skor konsistensi ilmiah tema 3.

Pada Gambar 8 terlihat bahwa sudah lebih sebagian siswa cukup konsisten dan benar dalam menentukan waktu 2 buah benda memiliki kecepatan yang sama, walaupun yang dapat konsisten dan benar dalam ketiga soal masih sepertiga dari seluruh siswa.

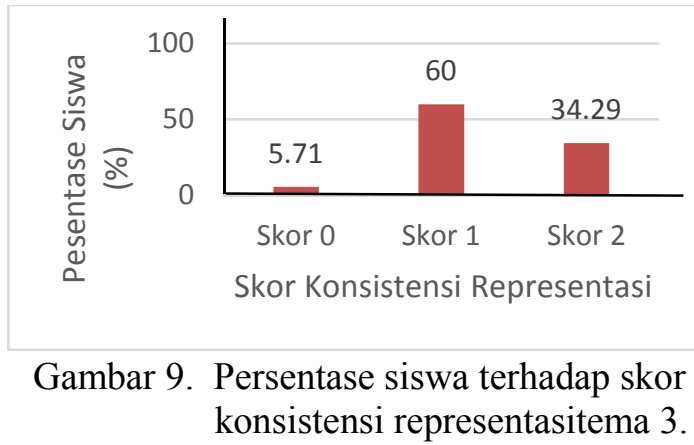

Gambar 9 dapat menunjukkan bahwa sebagian besar siswa sudah konsisten representasinya dalam menentukan waktu 2 buah benda memiliki besar kecepatan yang sama.

Rata-rata skor konsistensi ilmiah siswa pada tema 3 sebesar 1.07 (tidak konsisten ilmiah) dan rata-rata skor konsistensi representasi siswa pada tema 3 sebesar 1.29 (cukup konsisten ilmiah). Dapat dikatakan pada tema 3 ini yaitu pada konsep percepatan, siswa sudah konsisten dalam segi representasi tetapi masih belum dalam segi ilmiah atau kebenaran jawaban sesuai dengan konsep.

\section{Tema 4 gerak lurus beraturan}

Representasi yang digunakan pada tema 4 adalah grafik-verbal, gambar-grafik dan verbal-matematis. Dimana pada tema ini siswa dituntut agar konsisten dalam menentukan arah dan jarak tempuh masing-masing benda yang memiliki kecepatan konstan yang berbeda.
Besarnya persentase siswa pada tiap skor konsistensi ilmiah secara lebih lengkap dapat dilihat pada Gambar 10 dan untuk konsistensi representasi dapat dilihat pada Gambar 11.

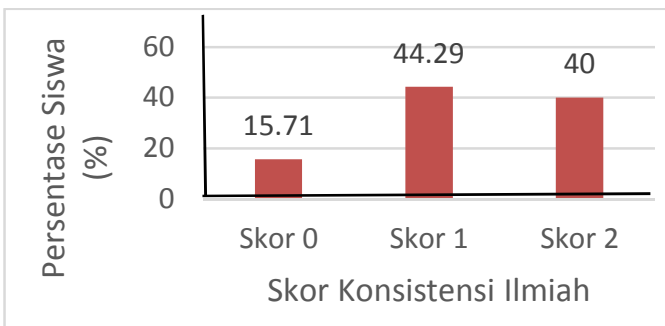

Gambar 10. persentase siswa terhadap skor konsistensi ilmiah tema 4.

Melalui Gambar 10 terlihat bahwa sudah sebagian besar siswa konsiten dan benar dalam memilih jawaban pada konsep gerak lurus beraturan.

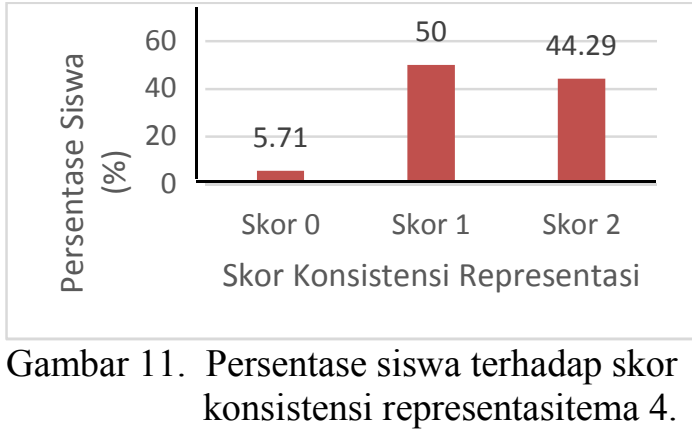

Pada Gambar 11 dapat dilihat bahwa sudah sebagian besar siswa konsisten dalam segi representasi pada soal dengan konsep gerak lurus beraturan.

Rata-rata skor konsistensi ilmiah siswa pada tema 4 sebesar 1.24 (cukup konsisten ilmiah) dan rata-rata skor konsistensi representasi siswa pada tema 4 sebesar 1.32 (cukup konsisten representasi), sehingga disimpulkan untuk tema 4 pada konsep gerak lurus beraturan siswa dapat dikatakan sudah konsisten baik dalam segi representasi maupun dalam segi ilmiah atau kebenarannya.

\section{Tema 5 gerak lurus berubah beraturan}

Representasi yang digunakan pada tema 5 adalah verbal-matematis, gambar-matematis dan grafik-matematis. Pada tema ini siswa diharuskan dapat konsisten dalam menentukan waktu yang dibutuhkan benda agara mencapai jarak tertentu, dimana salah satu bendanya 
bergerak dengan gerak lurus berubah beraturan.

Besarnya persentase siswa pada tiap skor konsistensi ilmiah secara lebih lengkap dapat dilihat pada Gambar 12 dan untuk konsistensi representasi dapat dilihat pada Gambar 13.

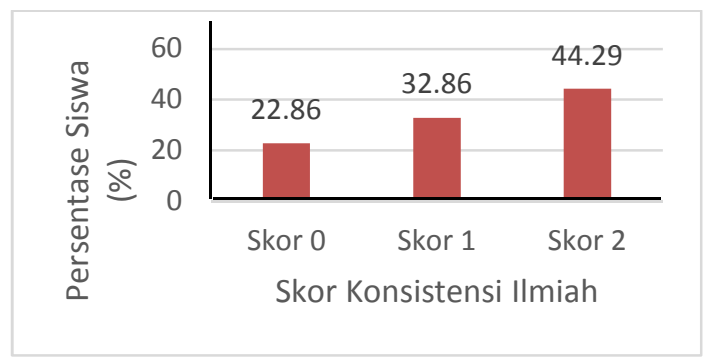

Gambar 12. Persentase siswa terhadap skor konsistensi ilmiah tema 5 .

Pada Gambar 12 terlihat bahwa lebih dari sebagian siswa sudah bisa konsisten dan benar dalam memilih jawaban pada soal dengan konsep gerak berubah beraturan.

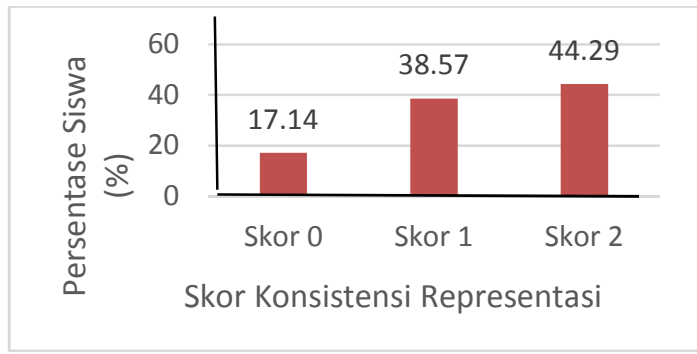

Gambar 13. Persentase siswa terhadap skor konsistensi representasitema 4.

Gambar 13 dapat dilihat bahwa sebagian besar siswa sudah bisa konsisten dalam segi representasi dalam memilih jawaban pada soal dengan konsep gerak berubah beraturan.

Rata-rata skor konsistensi ilmiah siswa pada tema 5 sebesar 1.21 (cukup konsisten ilmiah) dan rata-rata skor konsistensi representasi siswa pada tema 5 sebesar 1.27 (cukup konsisten representasi), sehingga disimpulkan untuk tema 5 pada konsep gerak lurus beraturan siswa dapat dikatakan sudah konsisten baik dalam segi representasi maupun dalam segi ilmiah atau kebenarannya secara konsep.

Tema 6 gerak vertikal ke atsa dan gerak vertikal ke bawah
Representasi yang digunakan pada tema 6 adalah verbal-grafik, grafik-verbal dan gambar-matematis. Pada tema ini siswa dituntut agar dapat konsisten dalam menentu kan nilai kecepatan akibat perbedaan arah dari kecepatan tersebut.

Besarnya persentase siswa pada tiap skor konsistensi ilmiah secara lebih lengkap dapat dilihat pada Gambar 14 dan untuk konsistensi representasi dapat dilihat pada Gambar 15.

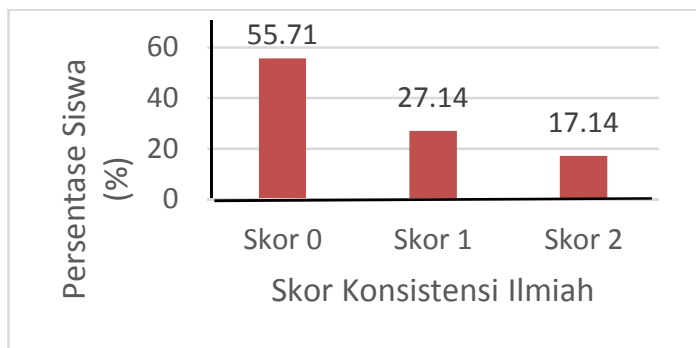

Gambar 14. Persentase siswa terhadap skor konsistensi ilmiah tema 6 .

Pada Gambar 14 terlihat bahwa masih lebih dari sebagian besar siswa belum bisa konsisten dan benar dalam memilih jawaban pada tema 6 ini.

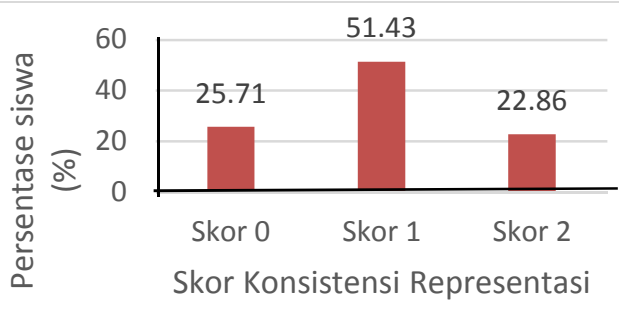

Gambar 15. Persentase siswa terhadap skor konsistensi representasi tema 6 .

Pada Gambar 15 dapat dilihat bahwa sudah lebih dari sebagian besar siswa bisa cukup konsisten dalam segi representasi, walaupun yang dapat konsisten dalam ketiga soal masih terbilang sedikit.

Rata-rata skor konsistensi representasi siswa pada tema 6 sebesar 0.97 (tidak konsisten representasi), sehingga disimpulkan bahwa untuk tema 6 pada konsep gerak vertikal ke atas dan gerak vertikal ke bawah siswa belum konsisten baik dalam segi representasi maupun dalam segi ilmiah atau kebenarannya. 


\section{Tema 7 gerak jatuh bebas}

Representasi yang digunakan pada tema 7 adalah verbal-matematis, grafik-matematis dan gambar-matematis. Pada tema ini siswa diharuskan dapat konsisten dalam menentukan besarnya jarak yang ditempuh oleh benda yang bergerak jatuh bebas.

Besarnya persentase siswa pada tiap skor konsistensi ilmiah secara lebih lengkap dapat dilihat pada Gambar 16 dan untuk konsistensi representasi dapat dilihat pada Gambar 17.

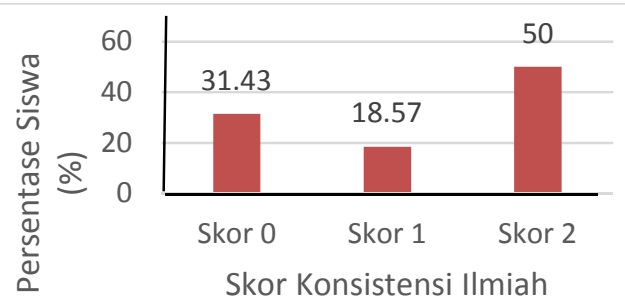

Gambar 16. Persentase siswa terhadap skor konsistensi ilmiah tema 7.

Pada Gambar 16 terlihat bahwa sudah lebih dari sebagian siswa dapat konsisten dan benar dalam memlilih jawaban, bahkan sudah sebagian dari seluruh siswa yang benar-benar konsisten dengan 3 jawabannya dari 3 soal yang disajikan.

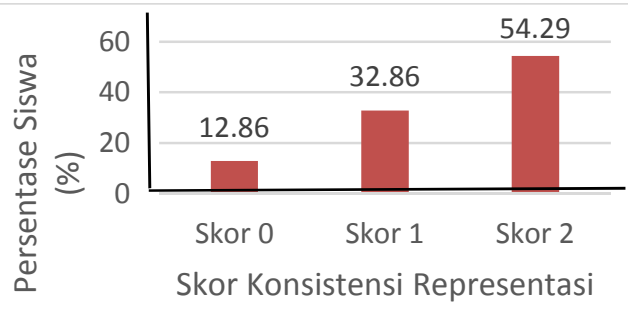

Gambar 17. Persentase siswa terhadap skor konsistensi representasi tema.

Pada Gambar 17 dapat dilihat bahwa sebagian besar siswa dapat konsisten dalam segi representasi pada tema 7 ini.

Rata-rata skor konsistensi ilmiah siswa pada tema 7 sebesar 1.20 (cukup konsisten ilmiah) dan rata-rata skor konsistensi representasi siswa pada tema 7 sebesar 1.41 (cukup konsisten representasi), sehingga disimpulkan bahwa pada tema 7 dengan soal yang menentukan jarak tempuh benda yang bergerak jatuh bebas siswa dapat dikatakan sudah konsisten baik dari segi representasi maupun dari segi ilmiah atau kebenarannya.

Hasil penelitian yang menunjukkan bahwa sudah $45.71 \%$ siswa sudah bisa konsisten untuk kategori konsistensi representasi, hal ini menyatakan bahwa sudah hampir sebagian siswa dapat menggunakan multi representasi secara konsisten terelepas dari jawabannya benar atau salah. Namun yang dinyatakan konsisten ilmiah dari keseluruhan siswa baru $34.29 \%$ siswa. Hal ini menunjukkan bahwa siswa yang dapat menggunakan representasi belum tentu memahami konsep fisika dengan benar. Asumsi ini diperkuat oleh pernyataan Nieminen, et al., (2010) yaitu walaupun memahami representasi tidak menjamin siswa memahami konsep fisika dengan benar, pemahaman siswa terhadap representasi tetaplah dibutuhkan untuk memfasilitasi pembelajaran.

Berdasarkan rekapitulasi jawaban siswa pada setiap format representasi yang disajikan, siswa lebih cendrung banyak dapat menjawab benar pada soal yang memiliki hubungan dengan representasi grafik (grafik-verbal, verbal-grafik, grafik-matematis) dan siswa lebih susah menjawab benar pada soal yang memiliki representasi gambar-matematis. Ini menunjukkan bahwa dalam menyelesaikan tes konsistensi ilmiah dan konsistensi representasi materi kinematika gerak lurus, siswa lebih dominan dalam penguasan representasi grafik. Hai ini sejalan dengan penelitian yang dilakukan Fatmawati, et al. (2015) yang juga menemukan bahwa kebenaran koresponden teringgi berada pada format grafik dan terendah pada format diagram.

Untuk mengatasi permasalahan terkait dengan konsistensi ilmiah dan konsistensi representasi siswa, pemahaman konsep dan kemampuan representasi merupakan dua hal yang perlu diperhatikan. Menurut Hestenes dalam Sriansyah (2015) kemampuan mengenali dan memanipulasi konsep dalam berbagai representasi adalah hal yang esensial. Kemampuan tersebut harus dilatihkan dalam setiap pembelajaran. Adapun pembelajaran yang sesuai tentu pembelajaran konseptual dan yang melibatkan penggunaan multi represen tasi di dalamnya. Pemanfaatan multi representasi berguna dalam melatih siswa untuk membuat, menginterpretasi, dan memanipulasi representasi pada suatu konsep 
(Van Heuvelen \& Zou, 2001). Dengan demikian, pembelajran semacam itu dapat meningkatkan pemahaman konsep dan konsistensi ilmiah dan konsistensi representasi siswa.

\section{Kesimpulan dan Saran}

Siswa kelas X SMAN 8 Pekanbaru secara keseluruhan berada pada tingkat tidak konsisten untuk konsitensi ilmiah atau siswa dikatakan belum memiliki konsistensi ilmiah. Sedangkan untuk konsistensi representasi secara keseluruhan siswa berada pada tingkat cukup konsisten atau siswa dikatakan sudah memliki konsistensi representasi.

Berdasarkan simpulan, maka peneliti merekomendasikan agar guru mengembangkan strategi atau model pembelajaran yang menggunaknan berbagai representasi dalam pembelajaran fisika suapaya dapat meningkat kan konsistensi ilmiah dan konsistensi representasi siswa. Bagi peneliti lain yang akan melakukan penelitian serupa, sebaiknya dilakukan pada subjek penelitian yang lebih luas dan pada materi lain yang banyak menggunakan multi representasi.

\section{Daftar Pustaka}

Abdurrahman, R., Aprilyawati, \& Payudi, 2008. "Limitation Of Representation Mode In Learning Gravitational Concept and Its Influence Toward Student Skill Problem solving". Proceeding of The 2nd International Seminar on Science education. PHY-31. p.373-377.

Ainsworth, S., 2006. A conceptual framework for considering learning with multiple representations. Learning and Instruction 16(3). p.183-198.

Aminudin, D., Sutiadi A., \& Samsudin. A., 2013. Profil Konsistensi Representasi dan Konsistensi Ilmiah Siswa SMP pada Konsep Gerak. Jurusan Pendidikan Fisika, Fakultas Pendidikan Matematika dan Ilmu Pengetahuan Alam Universitas Pendidikan Indonesia. 1 (3).

Binar, K., 2015. Pengembangan Perangkat Pembelajaran Fisika Model Inkuiri
Terbimbing untuk Melatihkan Kemampuan Multi Representasi Siswa SMA. Pendidikan Sains Pascasarjana Universitas Negeri Surabaya. 4 (2), 2089-1776.

Dya, Q. A., Sukarmin, \& Suparni, 2015. Pengaruh Pembelajaran Fisika Menggunakan Model Modified Free Inquiry Guided Inquiry terhadap Kemampuan Multirepresentasi Ditinjau dari Kemampuan Awal dan Keterampilan Proses Sains. Jurnal Inkuiri, 4(1), 2252-7893.

Etkina, E., Rosengrant, D., \& Van Heuvelen, A., 2006. Multiple Representations. Physics Education Research, 2, 020103.

Fatmawati, Muslimin, \& Kade A., 2015. Identifikasi Tingkat Konsistensi Representasi dan Pemahaman Konsep Mahasiswa pada Format Verbal, Grafik dan Diagram dalam Memecahkan Masalah Hukum III Newton. Jurnal Pendidikan Fisika Tadulako (JPFT), 4(1). p.33-38. 2338-3240.

Fathoroni, 2016. Konsistensi Representasi Besaran Fisis Materi Kinematika. Pros. Semnas Pend. IPA Pascasarjana UM., 1. 978-602-9286-21-2.

Goldin, G. A., 2002. Representation in Mathematical Learning and Problem Solving. L.D English (Ed). Handbook of International research in Mathematics Education(IRME). New Jersey: Lawrence Erlbaum Associates. 1.

Kohl, P.B., \& Noah D.F., 2008. Pattern of Multiple Representation Use by Expert and Novices During Physics Problem Solving. Physical Review Special Topics-Physics Education Research, 4 (1).

Nieminen, P., Savinainen, A., \& Virii, J., 2010. Force Concept Inventory-based Multiple-Choice Test for Investigating Students' Representational Consistency. Phys. Rev. ST. Phys. Educ. Res. 6 (2). 020109.

Nieminen, P., Savinainen, A., \& Virii, J., 2012. Relation between Representational Consistency, Conceptual Understanding of the Force Conc.

Sriyansyah, S. P., 2015. Analisis Konsistensi Representasi dan Konsistensi Ilmiah Mahasiswa pada Konsep Gaya Menggunakan Tes R-FCI. Indonesian 
Journal of Cience Education, 4 (1). p.75-82.

Sukardi, 2015. Metodologi Penelitian Pendidikan. Bumi Aksara, Jakarta .

Van Heuvelen, A. \& Zou, X., 2000. Multiple Representation of Work-Energy Processes. Am. J. Phys., 69(2), P.184194. 